\title{
Monsanto bypasses Mycogen with Bt synthetic genes
}

A Delaware US Federal Court has ruled that by selling products genetically engineered with a synthetic form of insecticidal Bacillus thuringiensis (Bt) crystal-protein gene, Monsanto (St. Louis, MO) and its partners are not infringing on two patents held by Mycogen (San Diego, CA) that describe a method for making synthetic forms of the gene. Monsanto, DeKalb Genetics (DeKalb, IL), and Delta \& Pine Land (Scott, MO) can sell Bollgard Bt cotton, YieldGard corn, and New Leaf potato seed, engineered with a synthetic $B t$ crystal-protein gene, without paying Mycogen royalties

In a closely watched biotechnology courtroom battle, the jury, after less than 2 days of deliberation, ruled on February 3 that Mycogen was not entitled to $\$ 70$ million in damages because the patents it held are invalid and do not provide any basis for a patent infringement claim. The patents describe a method of developing transgenic plants using a "synthetic or more modified" version of the native $B t$ crystal-protein DNA coding sequence of the gene. Without altering the $B t$ protein, the DNA structural coding sequence is altered to reflect the codon preference of the plant host and to exclude sequences that inhibit protein production in the plant. The resulting gene is expressed at a higher level in the plant, conferring an increased resistance to insect infestation.

Monsanto defended its position in the 2week trial with testimony from Monsanto biologist, Fred Perlak, who claimed that Monsanto, working independently, cloned the $B t$ gene in 1983. Changes were made to the DNA coding sequences to create the synthetic gene (via a different technique than Mycogen's) for use in corn in 1986; viable corn plants were grown in 1988 ahead of Mycogen scientists' work. "The verdict clarifies that Monsanto is the principal inventor in the field [of $B t$ technology]," says David Snively, Monsanto's general legal counsel.

The court's decision allows Monsanto and its partners to sell its lucrative insect-resistant corn, cotton, and potato seed without paying royalties to Mycogen, as invalidity of the Mycogen patents eliminates any proprietary position held by Mycogen for creating a synthetic gene and its insertion into plants. The ruling is especially important to DeKalbthe second largest corn-seed producerwhich would have had to pay royalties to Mycogen on its insect-resistant products had the patent been declared valid. "That would

Debra Robertson is a freelance writer working in San Diego, CA. have put real pressure on them," says Leonard Teitelbaum, agriculture analyst with broker Merrill Lynch (New York). This year, around $40 \%$ of US corn acreage will be planted with genetically altered seed containing the synthetic Bt genes.

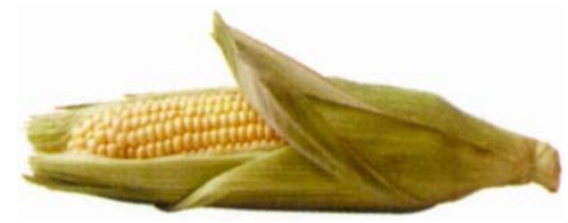

The decision allows Monsanto and partners to sell its insect-resistant corn without paying royalties to Mycogen.

However, DeKalb maintains cautious optimism. "We are gratified by the jury's ruling," says CEO Bruce Bickner. "We must keep in mind, however, that it may be years before the case is finally resolved, since it is likely Mycogen will ask the judge to rule on several post-trial motions and then seek to have the jury's verdict reversed on appeal." The decision to appeal the judgment is being considered by Mycogen president, Carl Eibl, who says that Mycogen feels that the judgment is flawed.

Independent of Mycogen's decision to appeal this judgment, the company and its competitors in the insect-resistant seed market are back in court defending several other patent-infringement suits. After the court's decision, Monsanto announced that it will proceed with an infringement suit in April against Mycogen and Novartis Seeds (Basel) to enforce a Monsanto patent describing its technique of creating synthetic $B t$ genes. At the same time, Plant Genetic Systems (a division of the Schering-Hoechst joint venture, AgrEvo; Ghent, Belgium) is bringing a separate suit against Mycogen in an attempt to enforce two of its $B t$ patents covering two particular shortened forms of the gene.

Mycogen believes that the court ruling will not affect it's ability to do business using $B t$ technology in plants, or to sell other pestresistant seeds in the area, which is expected to generate $\$ 100$ million this year. "The verdict does not create a proprietary position for Monsanto and thus does not affect Mycogen's ability to continue developing and commercializing $B t$ insect-resistant traits," says Eibl. "We hold dozens of US and foreign patents covering the industry's largest library of Bt genes."

Indeed, business will continue, but it is unknown what the long-term effects of losing a proprietary position on creating plants with synthetic versions of the $B t$ gene will have on Mycogen's ability to attract such companies as Pioneer HiBred (Des Moines, IA), which purchased 2 million shares of Mycogen stock in 1995 for access to Mycogen's large Bt gene library for use in its own products. With fewer genes now available in Mycogen's portfolio to license, and the future of many of the others now in the hands of the courts, seed companies interested in obtaining $B t$ genes for their products will be carefully watching the outcome of the Mycogen trials.

In response to the verdict, the stock price of DeKalb closed up 13.4\%, Delta \& Pine Land was up $2.7 \%$, and Monsanto was up $1.4 \%$. Mycogen fell $4.8 \%$.

Debra Robertson

\section{BIO calls for doubled NIH budget}

The US administration's budget for fiscal year (FY) 1999 calls for a significant 8\% increase over 1998 in civilian research and development programs, including several affecting biotechnology. Nonetheless, biotechnology company representatives are calling for much greater spending still in the area of health.

The budget request highlights several changes to regulatory agencies that oversee parts of the biotechnology industry and calls for the creation of an additional four user fee programs at the Environmental Protection Agency (EPA; Washington, DC).

The Clinton administration's budget requests an $8 \%$ increase for the NIH (Bethesda, MD) to $\$ 14.869$ billion in FY
1999. This is more than double the average increases for the NIH budget over the past few years, which have ranged from $2.6-5 \%$ each year since FY 1994. However, even before this $8 \%$ request was formally submitted to Congress, a broad coalition known as the Ad Hoc Group for Medical Research (Washington, DC) began lobbying for an even steeper $15 \%$ increase for the NIH. Carl Feldbaum, president of the Biotechnology Industry Organization (BIO, Washington, DC), which supports the Ad Hoc Group, says, "BIO is pleased with President Clinton's commitment to America's preeminent agency for medical research." He adds "We will press Congress to double the NIH budget during the next 5 years"-a proposal 